\title{
The Investigation of Green Practices, Green Innovation and Green Performance in Malaysian Automotive Industry
}

Juriah Conding, Anis Fadzlin Mohd Zubir, Suzaituladwini Hashim \& Nurzatul Ain Sri Lanang

Dept. of Accounting and Finance, Universiti Pendidikan Sultan Idris

35900 Tanjung Malim, Perak, Malaysia

Tel: 60-013-595-9391Ｅ-mail: juriahconding@yahoo.com

Nurul Fadly Habidin (Corresponding author)

Dept. of Management and Leadership, Sultan Idris Education University

35900 Tanjung Malim, Perak, Malaysia

Tel: 60-017-571-7027Ｅ-mail: fadly@fpe.upsi.edu.my

Received: November 14, 2012 Accepted: November 28, 2012

doi:10.5296/emsd.v2i1.2683～URL: http://dx.doi.org/10.5296/emsd.v2i1.2683

\begin{abstract}
Green practices and green innovation is most important as drivers for the industry to get more efficiency and effectiveness that can improve on green performance. This study is refer to analyze the drivers of green practices and green innovation and how automotive industry can adapts green practices and green innovation and which can effects on green performance for the green competitiveness of the automotive industry. Thus, the main purpose of this study is to develop a model that the structural analysis of green practices, green innovation and green performance in Malaysian automotive industry. The Structural Equation Modeling (SEM) has been proposed for conceptual model of this study. Base on the proposed conceptual model and reviewed, research hypotheses are being developed and the study culminates with opportunities for future research work.
\end{abstract}

Keywords: Green practices, green innovation, green performance, environmental, structural equation model, automotive industry

\section{Introduction}

Recently, the global automotive industry is undergoing a fundamental transformation due to increasing their performance through Green Practices (GP) and Green Innovation (GI). 
Subsequently, more than half of the surveyed in automotive industry start to focus in green factors, such as fuel economy, emissions and clean air regulations and actually all the factors are the industry's biggest challenges. Thus, to solving these challenges, the automotive industries need to stress the GP and emphasis on GI to enhancing their green performance.

Nowadays, most organizations trying to stress on quality initiatives and green technology that they was realized both of it is more important to improve their performance. Hence, industries need to apply of GP such as green supply chain management practices, green lean six sigma, and green balanced scorecard strategy to improving their profits and performance (Theyel, 2000). According to Zhu (2010), implementation of GP such as green purchasing, customer cooperation with green consideration, eco-design and investment recovery have made improvement for green performance. Green Jr. (2012) also support that GP are found to lead to improved green performance and organizational performance. Therefore, automotive industry should actively involved industry in the green management system effort, reduce waste strategy, strategic green improvement activities, development of green supply chains, and adoptability GI and technology advanced.

Besides that, many industries may consider more proactive environmental strategy in the near future. Thus, the automotive industry's positive contributions to the world economy are offset by its products and processes significant green impact. GI is also plays an important role in automotive industry, as well as having strong implications for the environment. Brunnermeier and Cohen (2003) have said that highly concentrated industries need to competitive pressure to GI. GI can defined as comprising of green product innovation, green process innovation and green managerial innovation in order to increased green performance (Chen et al., 2006; Chiou et al., 2011).

But, there is still considerable confusion and there is not clearly relation between the effect of GP on GI and green performance especially in Malaysian automotive industry. According to Nunes and Bennett (2010) that, in organization especially, the rules are changing again and there is enhancing stress for the implementation of GI is positively associated with GP to get more green performance. Chen (2008) also support with identified that GI and GP have a positive influence on a firm's ability to develop green product and process innovation and at same time it can helps to improve firm's green performance. Therefore, more efforts are required to study of green issues in Malaysian automotive industry. In order to fill the research gap, this study will investigate how automotive industries can improve their green performance by adoption of GP and GI.

\section{Literature Review}

Nowadays, the automotive industry in various countries around the world is in different stages of their environmental movements. GP and GI issues have emerged as primary concerns for industry to respond to a growing number of environmental regulations (Lin, 2011). Recent studies have begun to systematically explore the relationship between GP, GI and green performance. There are no previous studies focusing on environmental yet in Malaysian automotive industry but most of the studies just only reviewed in manufacturing process (Theyel, 2000; Rusinko, 2007; Zhu, et al., 2007; Chiou, et al., 2011; Green Jr, et al., 2012). 
Thus, we believe by exploring the GP and GI will be benefit toward Malaysian automotive industries in order to improve their green performance. Below shows Table 1 that defines the three variables of the study.

Table 1. Research Variables and Operational Definitions

\begin{tabular}{|c|c|c|c|}
\hline Dimension & Operational definiton & Measured variable & Literature \\
\hline $\begin{array}{c}\text { Green } \\
\text { Practices } \\
\text { (GP) }\end{array}$ & $\begin{array}{l}\text { Practices that committed to } \\
\text { created reducing negative } \\
\text { impacts of operations on the } \\
\text { environment }\end{array}$ & $\begin{array}{l}\text { Internal Environmental } \\
\text { Management (IEM) } \\
\text { Technology Integration } \\
\text { (TI) Logistic } \\
\text { Management (LM) } \\
\text { Customer Focus (CF) }\end{array}$ & $\begin{array}{l}\text { Esty and Winston (2006); } \\
\text { Vachon and Klassen, (2006); } \\
\text { Manaktola, (2007); } \\
\text { Zhu et al., (2008); } \\
\text { Jansson et al., (2010) }\end{array}$ \\
\hline $\begin{array}{c}\text { Green } \\
\text { Innovation } \\
\text { (GI) }\end{array}$ & $\begin{array}{l}\text { The innovation that a industry } \\
\text { carries out and involved in } \\
\text { energy-saving, pollution- } \\
\text { prevention, waste recycling, } \\
\text { green product and process } \\
\text { designs and corporate } \\
\text { environmental management }\end{array}$ & $\begin{array}{l}\text { Green product innovation } \\
\text { (GPTI) } \\
\text { Green process innovation } \\
\text { (GPSI) }\end{array}$ & $\begin{array}{l}\text { Brunnermeier and Cohen } \\
\text { (2003); } \\
\text { Chen et al., (2006); Chiou et } \\
\text { al., (2011); } \\
\text { Huang and Wu (2010); } \\
\text { Santamaria et. al., (2012) }\end{array}$ \\
\hline $\begin{array}{c}\text { Green } \\
\text { Performance }\end{array}$ & $\begin{array}{l}\text { Focus for the improvement of } \\
\text { environmental management to } \\
\text { the industry }\end{array}$ & $\begin{array}{l}\text { Environmental } \\
\text { performance } \\
\text { Economic performance } \\
\text { Operational performance } \\
\text { Innovation performance }\end{array}$ & $\begin{array}{l}\text { Rennings (2000); } \\
\text { Wagner et al., (2001); } \\
\text { Zhu et al., (2008); } \\
\text { Zhu and Sarkis (2004); Chien } \\
\text { and Shih (2007); Montabon } \\
\text { et al., (2007); Chiou et. al., } \\
\text { (2011) }\end{array}$ \\
\hline
\end{tabular}

\subsection{Green Practices (GP)}

Although previous studies have largely focused especially in manufacturing process but there is still can related adoption of GP in order to lead in industry automotive activities through green performance. Several researches have surveyed that there are positively relationship between GP and green performance. For example, according to Claver et al., (2007) indicates that adoption of GP have attained relatively better green performance outcomes. Ninkawan (2010) reported that GP as an important to helps industry to achieve profits and increasing competitive advantage. Besides that, Bergmiller and McCright (2009) have said that many companies have implemented GP which lead to increased green performance such as efficacy, reduced costs, improved customer response time, reduced energy consumption, waste generation, and hazardous materials usage.

Lin (2011) also suggested that the adoption of GP such as green supply chain management (green purchasing, green manufacturing, green packaging and reverse logistics) and total quality environmental management will given potential benefits to improve company green performance. According to Clemens (2001), he stressed that industry need to pass through three levels for their GP. The three levels that he mentioned are cost minimization, 
cost-effective compliance, and beneficial environmental controls given positively results to increasing industry's green performance. Thus, company should strive to achieve of benefits which may include improved green performance and image by implementation of GP (Zhu et al., 2008). Previous study in GP emphasizes that GP will lead the industry to become environmentally proactive and efficiency to get more efficient utilization of resources and improved corporate image (Montabon, 2007). GP implementation can only slightly improve to the industry's green performance and it plays an important to lead the industry to get more profit and increase their competitive advantage (Zhu et al., 2007).

An important factor in implementation of GP is management related to the environment (Azavedo et al., 2011). GP can be denominated product recycling, environmental compliance and optimization in order to improve green performance (Mahmood et al., 2011). Therefore, through on results of previous study (Vachon \& Klassen, 2006; Esty and Winston, 2006; Manaktola, 2007; Zhu et al., 2008; Jansson et al., 2010; Green, Jr, et al., 2012) that this study come out with conceptualize of GP constructs as associated with different characteristics of GP including internal environmental management, technology integration, logistic management, customer focus and, supplier management as antecedents. Definitions of the constructs of GP incorporated in Table 2.

Table 2. Construct Definitions of Green Practices

\begin{tabular}{|l|l|}
\hline \multicolumn{1}{|c|}{ Constructs } & \multicolumn{1}{c|}{ Operational definition } \\
\hline $\begin{array}{l}\text { Internal } \\
\text { Environmental }\end{array}$ & $\begin{array}{l}\text { The practice of developing environmental as a strategic organizational } \\
\text { imperative from senior and mid-level managers (Zhu et al., 2008) }\end{array}$ \\
\hline $\begin{array}{l}\text { Technology } \\
\text { Integration (TI) }\end{array}$ & $\begin{array}{l}\text { Technological integration can be defined as tacit knowledge sharing taking place } \\
\text { between a buying and a supplying organization in strategic areas like product } \\
\text { development, process reengineering, and technical training (Vachon and } \\
\text { Klassen, 2006), the systems that have been modified and are used to monitor } \\
\text { green practices and outcomes (Esty and Winston, 2006) }\end{array}$ \\
\hline $\begin{array}{l}\text { Logistic } \\
\text { Management (LM) }\end{array}$ & $\begin{array}{l}\text { The integrated life-cycle management of green practices flowing from supplier, } \\
\text { through to manufacturer, customer, and closing loop with reverse logistics } \\
\text { (Vachon and Klassen, 2006; Zhu et al., 2008) }\end{array}$ \\
\hline $\begin{array}{l}\text { Customer Focus } \\
\text { (CF) }\end{array}$ & $\begin{array}{l}\text { Cooperation with customers that affect the design and development of their } \\
\text { customer's environmental practices (Manaktola, 2007; Zhu et al., 2008; Jansson } \\
\text { et al., 2010) }\end{array}$ \\
\hline Supplier Focus (SF) & $\begin{array}{l}\text { Cooperation with suppliers that purpose of developing products that are } \\
\text { environmentally (Zhu et al., 2008) }\end{array}$ \\
\hline
\end{tabular}

\subsection{Green Innovation (GI)}

There are several empirical studies analyzing about GI that given positively and negatively results that can effects to company's green performance. Carrion-Flores and Innes (2010) posited that GI is an important driver of reductions especially in toxic emissions that can lower firm's cost of meeting tighter government or consumer or NGO pollution targets, spurring successful demands for green performance. Meanwhile, factors that influence on GI 
in industry such as corporate environmental commitment, environmental benchmarking, R\&D strength, and cross functional integration can increased industry's green performance (Huang and $\mathrm{Wu}, 2010$ ). Besides that, industry will gain cost savings, increased efficiency, increased productivity and better product quality by adoption of GI (Chiou et al., 2011). Recently, most of the previous studies have found that GI is a driver that can correlate and helpful in order to enhance performance and reduce environmental burdens in industry (Chen, 2006).

But, the result by Ramanathan, Horbach, Chen and Chang are different than others researchers. Ramanathan (2010) indicates that there is no relationship between GI and green performance which is environmental regulation negatively influence on innovation and GI negatively influences in green performance. According to Horbach (2008), GI represent negative external effects so that there is no clear economic incentive to develop new environmentally especially product and processes. This also support by Chen and Chang (2011) asserted that effects of GI can divided into two parts; when the GI of companies is low, GI has linear positively influence to the company in competitive advantage but when the GI companies is high, GI has nonlinearly influence to competitive advantage.

Thus, as viewed in different result from all researchers that GI can relate in different of green performance improvements. The constructs of GI below was referred study by (Brunnermeier and Cohen, 2003; Chen et al., 2006; Chiou et al., 2011; Huang and Wu, 2010; Santamaria et. al., 2012; Conding et al., 2012a) that GI can separately in different constructs such as Green Product Innovation (GPTI) and Green Process Innovation (GPSI) performance as consequences for this study. Definitions of the constructs of GP incorporated in Table 3.

Table 3. Construct Definition of Green Innovation

\begin{tabular}{|l|l|}
\hline \multicolumn{1}{|c|}{ Construct } \\
$\begin{array}{l}\text { Innoen Product } \\
\text { (GPTI) }\end{array}$ & $\begin{array}{l}\text { Product that is related to environmental innovation, including the innovation in } \\
\text { product that are new or that offer a significant improvement on the basic } \\
\text { characteristic, technical specification, incorporated software or any components or } \\
\text { materials and the product that introduced are involved in energy-saving, } \\
\text { pollution-prevention, waste recycling, no toxicity, or green product design, using less } \\
\text { or non-polluting/ toxic materials, improving and designing environmentally friendly } \\
\text { packaging for existing and new products, recovery of company's end-of-life products } \\
\text { and recycling (Chen et al., 2006; Santamaria et. al., 2012; Brunnermeier and Cohen, } \\
\text { 2003; Chiou et al., 2011; Huang and Wu, 2010; Conding et al., 2012) }\end{array}$ \\
\hline $\begin{array}{l}\text { Green Process } \\
\text { Innovation }\end{array}$ & $\begin{array}{l}\text { Process that assumed to happen when it has implemented new or significantly } \\
\text { improved production processes, distribution new methods or support activities for } \\
\text { its good and services and the process is related to energy- saving, pollution- } \\
\text { prevention, waste recycling, or no toxicity, low energy consumption, recycle, reuse } \\
\text { and remanufacture material and use of cleaner technology to make savings and } \\
\text { prevent pollution (Chen et al., 2006; Santamaria et. al., 2012; Brunnermeier and } \\
\text { Cohen, 2003; Chiou et al., 2011; Conding et al., 2012) }\end{array}$ \\
\hline
\end{tabular}




\subsection{Link between Green Practices and Green Innovation}

Several researchers studying GP claims that there are relationship between GP and GI to increased profits and improved industry's green performance (Sanchez, 1998; Chiou et al., 2011). For example, studied by Chan (2011) GP can moderates with GI leads to better competitive advantage than the direct effect. GP are associated with GI to increases the incentive and thus the probability of a firm carrying out a GI (Wagner, 2008). It is also support by Theyel (2000) that the adoption of GP such as training programs, R\&D, evaluations of suppliers and employee incentive programs for environmental improvement in industry given positively effects on GI with their production inputs and production processes for reducing pollution. The implementation of GP can related with GI that Malaysian automotive industry can develop strategies to get more green sustainability abilities to reduce pollution and negative risk and impacts of resource use.

\subsection{The Positive effects of Green Practices (GP) and Green Innovation (GI) on Green Performance}

GP and GI efforts have improved its green performance that support through various strategies, initiatives achieved and created opportunities to the company (Rennings, 2000; Wagner et al., 2001; Zhu and Sarkis, 2004; Chien and Shih, 2007; Zhu et al., 2008; Chiou et. al., 2011; Comoglio and Botta, 2012; Conding et al., 2012a; Conding et al., 2012b). According to Montabon et al., (2007) that GP and GI strategy can be an incentive for companies to make continuous efforts on environmental improvements to their green performance beyond green regulations.

As viewed a whole studies, there might be different of GP and GI that it can indicate in different green performance improvements. Thereby, these study separately in different green performance measures such as environmental, economic, operational and innovation performance as consequences for this study. There for, below shows definitions of GP measure incorporated in Table 4.

Table 4. Measure of Green Performance

\begin{tabular}{|l|l|}
\hline Measure & Definition \\
\hline $\begin{array}{l}\text { Environmental } \\
\text { Performance }\end{array}$ & $\begin{array}{l}\text { Environmental performance relates the ability of manufacturing plants to reduce air } \\
\text { emissions, effluent waste, and solid wastes and the ability to decrease consumption } \\
\text { of hazardous and toxic materials (Wagner } \text { et al., 2001; Zhu and Sarkis, 2004; Chien } \\
\text { and Shih, 2007; Montabon } \text { et al., 2007; Zhu } \text { et al., 2008; Chiou } \text { et. al., 2011). }\end{array}$ \\
\hline $\begin{array}{l}\text { Economic } \\
\text { Performance }\end{array}$ & $\begin{array}{l}\text { Economic performance relates to the manufacturing plant's ability to reduce costs } \\
\text { associated with purchased materials, energy consumption, waste treatment, waste } \\
\text { discharge, and fines for environmental accidents (Wagner } \text { et al., 2001; Zhu and } \\
\text { Sarkis, 2004; Zhu } \text { et al., 2008). }\end{array}$ \\
\hline $\begin{array}{l}\text { Operational } \\
\text { Performance }\end{array}$ & $\begin{array}{l}\text { Operational performance relates to the manufacturing plant's capabilities to more } \\
\text { efficiently produce and deliver products to customers (Chien and Shih, 2007; Zhu } \\
\text { et al., 2008) }\end{array}$ \\
\hline Innovation & Innovation performance can defined as measures of green innovation in develop \\
\hline
\end{tabular}


Performance

\section{Research Framework and Hypotheses Development}

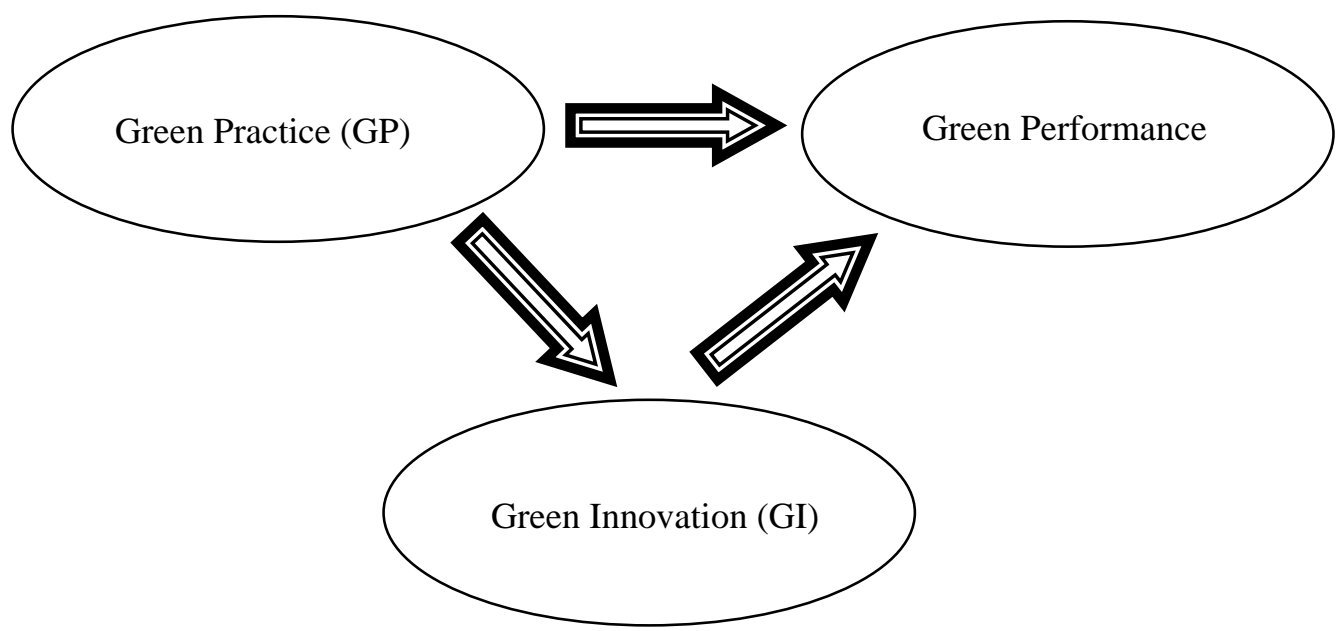

Figure 1. Framework of the Study

The research framework is shown in Figure 1 above, is develop to investigate the relationships between GP (IEM, TI, LM, CF, and SF) and GI (GPTI and GPSI). This regulation is also thought to impact upon the levels of GP and GI in an industry.

The most of current literature, there are many organizations that purport to have incorporated green impacts into their practices and innovation. According to Ishak et al., (2011) indicates that when implementing the GP and GI as it would change the culture through the vision that the organization bring. Besides that, mediating of GP and GI, organization or industries need to find ways to optimize the organizational innovation that can improve their organizations' competencies. The implementation and diffusion of green impacts have been actively done across the organizations throughout the world as a means to improve the quality and working environment. Despite the evidence by Zhu et al., (2005) that more organization have increased their environmental awareness such as regulatory, competitive, and marketing pressures and drivers and strongly stress on GP adoption emerged with GI into improvements in some areas of performance.

The relationship of GP on GI in Malaysian automotive industry is through on literature review above and the research framework. To understand more about the relationship between GP, GI and green performance in Malaysian automotive industry, a number of hypotheses derived from the framework and discussion above can be stated as below:

$\mathbf{H}_{1}$ : $\quad$ There is a positive and direct significant relationship between green practices implementation and green performance in Malaysian automotive industry

$\mathbf{H}_{2}$ : $\quad$ There is a positive and direct significant relationship between green practices implementation and green innovation in Malaysian automotive industry

$\mathbf{H}_{3}$ : There is a positive and direct significant relationship between green innovation 


\section{$\mathbf{H}_{4}$ : $\quad$ The impact of green practices implementation on green performance increases with a mediating of green innovation in Malaysian Automotive industry}

The hypotheses above were set up to be tested and developed through literature review above. These hypotheses will be stated based on a numbering system from $\mathrm{H} 1$ to $\mathrm{H} 4$. The hypotheses will tested by using data collect with measured variables are obtained from respondents in response to a set of questionnaire. Researcher will use SEM to test the hypotheses. This style of hypothesis statement is chosen due to the nature of answering hypotheses using SEM methods. Based on the above hypotheses, Figure 2 shows a summary of the hypotheses for the proposed research model.

\section{A Proposed Research Model}

A proposed research model was based on comprehensive review of previous studies, the research model aims at analyzing the impact of the relationship between GP and GI for Malaysian automotive industries. This model is called mediating model as presented in Figure 2.

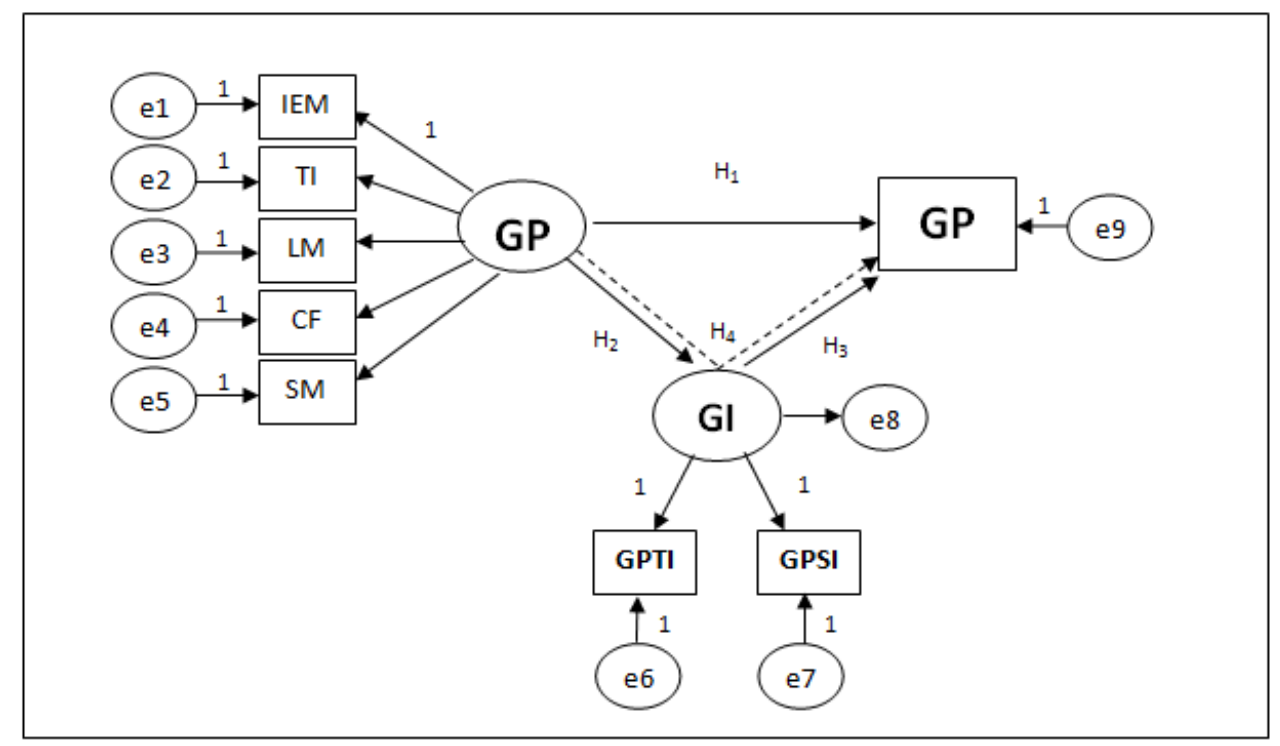

*Note: GP=Green Practices, GI= Green Innovation, GP=Green Performance, IEM= Internal Environmental Management, TI= Technology Integration, LM= Logistic Management, CF=Customer Focus, SM= Supplier Management, GPTI=Green Product Innovation, GPSI= Green Process Innovation.

Figure 2. A Proposed Conceptual Model of GP, GI and Green Performance for Malaysian Automotive Industry

\section{Methodology}

Automotive industry is a large scale manufacturer, massive, competitive and global industry (Bradley et al., 2005; Kuik, 2006). Researcher was chosen automotive industry as a population of this study because the industry is an ongoing and focuses on environmental issues that will give strong pressures to the environmental burdens and new legislations to preserve nature and avoid global warming (Gonzalez, 2008; Zakuan et al., 2009). 


\section{Macrothink}

The population of this study comprised in Malaysian automotive industry. The sample should be a subset of the total population, which has the characteristics of the population (Jackson, 2011). To achieving the objectives of the study, the Malaysian automotive suppliers firms were selected as the population and the data was obtained from PROTON Vendor Association (PVA) and Kelab Vendor PERODUA (KVP). Therefore, samples were selected from the list of PROTON and PERODUA automotive suppliers. Structured questionnaire was using as a sampling method. These lists of automotive suppliers consist of electrical, electronic, metal, plastic, rubber, and other automotive part.

The statistical Package for the Social Sciences (SPSS) version 17 was used to analyze the preliminary data and provide descriptive analyses about thesis sample such as means, standard deviations, and frequencies. SEM using AMOS 6.0 will use to test the measurement model. SEM techniques was utilize to perform the require statistical analysis of the data from the survey. Exploratory factor analysis, reliability analysis and confirmatory factor analysis to test for construct validity, reliability, and measurements loading were performed. Having analyzed the measurement model, the structural model was then tested and confirmed.

\section{Conclusion}

In the conclusions, GP and GI a very important for an organization's ability to adopt their activities with new environmentally effective to improve their green performance. Nowadays, successful automotive industry in Malaysia posses at least GP and GI can attributes such as production efficiency, well-planned cost structures, manageable size, distributed management of brands, attention to underserved markets, focused strategy, and well-respected brands and products. Thus, GP and GI are most important to get all the attributes because it is needed to involve in local car manufacturers and automotive suppliers in their effort to increased green impact and green initiatives to the industry.

Based on proposed model and a previous study, research hypotheses are being developed. The next step of this study is to design a questionnare, which will be used for pilot study data collection in automotive industry in Malaysia. This study expected to provide valid and reliable for instrument and structural relationship model for GP and GI constructs and green performance measures. A conceptual model has been proposed to examine the relationships between GP, GI and green performance in the automotive industry in Malaysia.

\section{Acknowledgement}

The researchers would like to acknowledge the Ministry of Higher Education (MOHE) for the financial funding of this research thought Fundamental Research Grant Scheme (FRGS), and Research Management Centre (RMC) UPSI for Research University Grant (RUG).

\section{References}

Azavedo, S., Carvalho, H., \& Machado, V. C. (2011). The influence of green practices on supply chain performance: A case study approach. Transportation Research Part E, 47, 850-871. http://dx.doi.org/10.1016/j.tre.2011.05.017

Bergmiller, G. G. \& McCright, P. R. (2009). Parallel models for lean and green operations. 
Proceedings of the Industrial Engineering Research Conference, Zero Waste Operations Research and Consulting, USA.

Bradley, D., Bruns, M., Fleming, A., Ling, J., Margolin, L., and Roman, F. (2005). Automototive industry analysis. [Online] Available: http://www.srl.gatech.edu/Members/bbradley/me6753.industryanalysis.teamA.pdf (Sept 05, 2012).

Brunnermeier, S. B. \& Cohen, M. A. (2003). Determinants of environmental innovation in US manufacturing industries. Journal of Environmental Economics and Management, 45, 278-293. http://dx.doi.org/10.1016/S0095-0696(02)00058-X

Comoglio, C. \& Botta, S. (2012). The use of indicators and the role of environmental management systems for environemtal performances improvement: a survey on ISO 14001 certified companies in the automotive sector. Journal of Cleaner Production, 20, 92-102. http://dx.doi.org/10.1016/j.jclepro.2011.08.022

Chan, H. K. (2011). Green process and product design in practice. The 2011 International (European) Conference on Asia Pacific Business Innovation and Technology Management. Procedia: Social and Behavioral Sciences, 25, 398-402.

Conding, J., Habidin, N. F., Zubir, A. F. M., Hashim, S., \& Jaya, N. A. S. L. (2012a). The structural analysis of green innovation (GI) and green performance (GP) in Malaysian automotive industry. Research Journal of Finance and Accounting, 3(6), 172- 178.

Conding, J., Habidin, N. F., Zubir, A. F. M., Hashim, S., \& Jaya, N. A. S. L. (2012b). A proposed of green practices and green innovation model in Malaysian automotive industry. Environmental Management and Sustainable Development, 1(2), 90-100.

Chen, Y.-S., Lai, S.-B., \& Wen, C.-T. (2006). The influence of green innovation performance on corporate advantage in Taiwan. Journal of Business Ethics, 67, 331-339. http://dx.doi.org/10.1007/s10551-006-9025-5

Chen, Y.-S. \& Chang, K.- C. (2011). The nonlinear effect of green innovation on the corporate competitive advantage. Spinger Science Business Media B. V., 1-16.

Carrion-Flores, C. E. and Innes, R. (2010). Environmental innovation and environmental performance. Journal Environmental Economics and Management, 59, 27-42. http://dx.doi.org/10.1016/j.jeem.2009.05.003

Chiou, T-Y., Chan H. K, Lettice, F., \& Chung, S. H. (2011). Influence of greening the suppliers and green innovation on environmental performance and competitive advantage. Transportation Research Part E, 47, 822-836. http://dx.doi.org/10.1016/j.tre.2011.05.016

Clemens, B. (2001). Changing environmental strategies over time: An empirical study of the steel industry in the United States. Journal Environmental Management, 62, 221-231.

http://dx.doi.org/10.1006/jema.2001.0426

Claver, E., Lopez, M. D., Molina J. F., \& Tari, J. J. (2007). Environmental management and 


\section{Macrothink}

firm performance: A case study. Journal of Environmental Management, 84 (4), 606-619. http://dx.doi.org/10.1016/j.jenvman.2006.09.012

Chiou, T.-Y., Chan, H. K., Lettice, F., \& Chung, S. H. (2011). The influence of greening the suppliers and green innovation on environmental performance and competitive advantage in Taiwan. Transportation Part E, 47, 822-836. http://dx.doi.org/10.1016/j.tre.2011.05.016

Chen, Y.-S., Lai, S.-B., \& Wen, C.-T. (2006). The influence of green innovation performance on corporate advantage in Taiwan. Journal of Business Ethics, 67 (4), 331-339. http://dx.doi.org/10.1007/s10551-006-9025-5

Esty, D. \& Winston, A. (2006). Green to gold: How smart companies use environmental strategy to innovate, create value and build competitive advantage, Yale University Press, New Haven, CT.

Gonzalez, P., Sarkis, J., \& Adenso-Diaz, B. (2008). Environmental management system certification and its influence on corporate practices. International Journal of Operations \& Production Management, 28 (11), 1021-1041. http://dx.doi.org/10.1108/01443570810910179

Green Jr., K. W., Zelbst, P. J., Meacham, J., \& Bhadauria, V. S. (2012). Green supply chain management practices: Impact on performance. An International Journal, 17 (3), 1-44.

Horbach, J. (2008). Determinants of environmental innovation- New evidence from German panel data sources. Research Policy, 37, 163-173. http://dx.doi.org/10.1016/j.respol.2007.08.006

Huang, Y.-C. \& Wu, Y.-C. J. (2010). The effects of organizational factors on green new

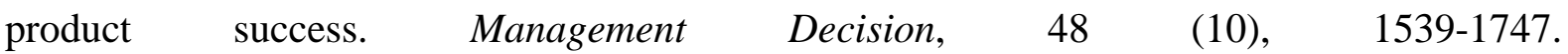
http://dx.doi.org/10.1108/00251741011090324

Ishak, N. A., and Ahmad, H. (2011). Emerging themes of the leadership and green innovation of the government-Linked companies. IBIMA Publishing, 1-9.

Jackson, S. L. (2011). Research methods and statistics: A critical thinking approach.Wadsworth Cengage Learning, United States, America.

Jansson, J., Marell, A., \& Nordlund, A. (2010). Green consumer behavior: Determinants of curtailment and eco-innovation adoption. Journal of Consumer Marketing, 27 (4), 358-370.

http://dx.doi.org/10.1108/07363761011052396

Kuik, O. (2006). Environmental innovation dynamics in the automotive industry. A case study in the framework of the project assessing in innovation dynamics induced by environment policy. Institute for Environmental Studies, Vrije University, The Netherlands.

Lin, R.-J. (2011). Moderating effects of total quality environmental management on environmental performance. African Journal of Business Management, 5(20), 8088-8099.

Mahmood, W., H., W., Rahman, M., N., A., \& Deros, B., M. (2011). The relationship between manufacturing system performance and green practices in supply chain management. World Academy of Science, Engineering and Technology, 59, 2454-2458. 


\section{Macrothink}

Environmental Management and Sustainable Development

ISSN 2164-7682 2013, Vol. 2, No. 1

Manaktola, K. \& Jauhari, V. (2007). Exploring consumer attitude and behavior towards green practices in the lodging industry in india. International Journal of Contemporary Hospitality Management, 19 (5), 364-377. http://dx.doi.org/10.1108/09596110710757534

Montabon, F., Sroufe, R., \& Narasimhan, R (2007). An examination of corporate reporting, environmental management practices and firm performance. Journal of Operations Management, 25, 998-1014. http://dx.doi.org/10.1016/j.jom.2006.10.003

Ninlawan, C., Seksan, P., Tossapol, K., \& Pilada, W. (2010). The implementation of green supply chain management practices in electronics industry. Proceedings of the International Multi Conference of Engineers and Computer Scientists (IMECS 2010), Vol 3, Hong Kong.

Nunes, B. \& Bennett, D. (2010). Green operations initiatives in the automotive industry: An environmental reposts analysis and benchmarking study. An International Journal, 17 (3), 396-420.

Sanchez, C. M. \& Mckinley, W. (1988). Environmental regulatory influence and product innovation: The contingency effects of organizational characteristics. J. Eng. Technology Management, 15, 257- 278. http://dx.doi.org/10.1016/S0923-4748(98)00017-4

Santamaria, S., Nieto, M. J., \& Miles, I. (2012). Service innovation in manufacturing firms: Evidence from Spain. Journal Technovation. 32, 144-155. http://dx.doi.org/10.1016/j.technovation.2011.08.006

Theyel, G. (2000). Management practices for environmental innovation and performance. International Journal of Operations \& Production Management, 20 (2), 249-266. http://dx.doi.org/10.1108/01443570010304288

Vachon, S. \& Klassen, R. D. (2006). Extending green practices across the supply chain. International Journal of Operations \& Production Management, 26 (7), 795-821. http://dx.doi.org/10.1108/01443570610672248

Wagner, M. (2008). Empirical influence of environmental management on innovation: Evidence from Europe. Ecological Economics, 66, 392-402. http://dx.doi.org/10.1016/j.ecolecon.2007.10.001

Zakuan, N. M. (2009), Structural analysis of total quality management, ISO/TS 16949 and organizational performance in Malaysian and Thailand automotive industry, PhD Thesis, Faculty of Mechanical Engineering, Universiti Technology Malaysia, Malaysia.

Zhu, Q., Geng, Y., Fujito, T., \& Hashimoto, S. (2010). Green supply chain management in leading manufacturers. Management Research Review, 33 (4), 380-392. http://dx.doi.org/10.1108/01409171011030471

Zhu, Q., Sarkis, J., \& Kee-hung, L. (2008). Confirmation of a measurement model for green supply chain management practices implementation. Int. J. Production Economics, 111, 261-273. http://dx.doi.org/10.1016/j.ijpe.2006.11.029

Zhu, Q., Sarkis, J., \& Lai, K-H. (2007). Green supply chain management: pressures, practices 


\section{Macrothink}

and performance within the Chinese automobile industry. Journal of Cleaner Production, 15, 1041-1052. http://dx.doi.org/10.1016/j.jclepro.2006.05.021

Zhu, Q. \& Sarkis, J., (2004). Relationships between operational practices and performances among early adopters of green supply chain management practices in Chinese manufacturing enterprise. Journal of Operations Management, 22, 265-289. http://dx.doi.org/10.1016/j.jom.2004.01.005

Zhu, Q., Sarkis, J., \& Geng, Y. (2005). Green supply chain management in China: pressures, practices and performance. International Journal of Operations \& Production Management, 25 (5), 449-468. http://dx.doi.org/10.1108/01443570510593148

\section{Copyright Disclaimer}

Copyright reserved by the author(s).

This article is an open-access article distributed under the terms and conditions of the Creative Commons Attribution license (http://creativecommons.org/licenses/by/3.0/). 